\title{
НОРМАТИВНО-ПРАВОВІ ЗАСАДИ ЗДІЙСНЕННЯ НОТАРІАТОМ ПРАВООХОРОННОЇ ФУНКЦІї ДЕРЖАВИ
}

Савицька Н. А.

\begin{abstract}
У статті виконано аналіз нормативно-правових засад, що визначають здійснення нотаріатом правоохоронної функції держави. 3'ясовано, що базовим для здійснення нотаріальної діяльності є Закон України «Про нотаріат». Обгрунтовано недосконалість законодавчої бази про нотаpiam, необхідність уточнення окремих понять вимагає його реформування, яке має здійснюватися в напрямі система тизації. Зазначено, що здійснення нотаріальний дій передбачає охорону та захист основних прав і свобод фізичних і юридичних осіб, унеможливлює їх порушення. У такий спосіб нотаріат здійснює правоохоронну функцію, а разом із цим $\epsilon$ інструментом реалізації правоохоронної функції державою. 3'ясовано, що в законодавстві не існує визначення правоохоронної функції, а ії здійснення відбувається через правоохоронну діяльність відповідних суб'єктів. Нотаріат входить до складу системи правоохоронних органів в Україні, на які покладається обов'язок сприяти реалізації прав і свобод фізичних і юридичних осіб у державі. Діяльність нотаріату в Україні регулюється значною кількістю різнорівневих нормативно-правових актів, що створює труднощі в їх застосуванні. Базовим для здійснення нотаріальної діяльності є Закон України «Про нотаріат». Недосконалість законодавчої бази про нотаріат і необхідність уточнення окремих понять вимагає його реформування, яке має здійснюватися в напрямі систематизації. Зроблено висновок, що нотаріуси та посадові особи, які вчиняють нотаріальні діi, вирішують лише безспірні справи, ураховуючи оцінку наданих документів, які не мають містити розбіжностей i суперечностей.
\end{abstract}

Ключові слова: нотаріат, нормативно-правові засади, правоохоронна функція держави, нормативно-правова база, законодавство, повноваження.

B cтатье проведен анализ нормативно-правовых основ, определяющих осуществление нотариатом пра воохранительной функции государства. Определено, что базовым для осуществления нотариальной деятельности является Закон Украины «О нотариате». Обоснованно несовершенство законодательной базы о нотариате, необходимость уточнения отдельных понятий требует его реформирования, которое должно осуществляться в направлении систематизации. Указано, что осуществление нотариальных действий предусматривает охрану и защиту основных прав и свобод физических и юридических лиц, исключает их нарушения. Таким образом, нотариат осуществляет правоохранительную функцию, а вместе с этим является инструментом реализации правоохранительной функции государством. Установлено, что в законодательстве не существует определения правоохранительной функции, а ее осуществление происходит через правоохранительную деятельность соответствующих субъектов. Нотариат входит в состав системы правоохранительных органов в Украине, на которые возлагается обязанность способствовать реализации прав и свобод физических и юридических лич в государстве. Деятельность нотариата в Украине регулируется значи-

Савицька Н. А., 2019 тельным количеством разноуровневых нормативно-правовых актов, что создает трудности в их применении. Базовым для осуществления нотариальной деятельности является Закон Украины «О нотариате». Несовершенство законодательной базы о нотариате и необходимость уточнения отдельных понятий требуют его реформирования, которое должно осуществляться в направлении систематизации. Сделан вывод, что нотариусы и должностные лица, совершающие нотариальные действия, решают только бесспорные дела, учитывая оценку предоставленных документов, которые не должны содержать разногласий и противоречий.

Ключевые слова: нотариат, нормативно-правовые основы, правоохранительная функция государства, нормативно-правовая база, законодательство, полномочия.

The article analyzes the legal framework that determines the notary's performance of the state's law enforcement function. It is determined that the basis for notarial activity is the Law of Ukraine "On Notary". The imperfection of the legal basis on a notary is justified and the need for clarification of certain concepts requires its reform, which should be carried out in the direction of systematization. It is noted that the implementation of notarial acts provides for the protection and protection of fundamental rights and freedoms of individuals and legal entities, prevents their violation. In this way, the notary performs a law enforcement function, and at the same time is a tool for the implementation of the law enforcement function by the state. It is found that the law does not define the law enforcement function, and its implementation occurs through the law enforcement activities of the respective entities. The notary is a part of the system of law enforcement agencies in Ukraine, which have a duty to promote the rights and freedoms of individuals and legal entities in the country. Notary activity in Ukraine is regulated by a large number of different levels of legal acts, which creates difficulties in their application. The basis for notarial activity is the Law of Ukraine "On Notary". The imperfection of the legal framework on a notary and the need to clarify certain concepts requires its reform, which should be carried out in the direction of systematization. It is concluded that notaries and officials who perform notarial acts only resolve unchallenged cases, taking into account the evaluation of documents submitted, which should be free of differences and contradictions. The list of notarial acts and the procedure for their implementation are set out in the legislation. Among them are the certificate of power of attorney, contracts of alienation of real estate, land, vehicles, contracts of rent (lease), pledge agreements, mortgage and other contracts, wills, attestation of correctness of copies (photocopies) of documents, authenticity signatures on documents, initiation of inheritance cases, issuance of certificates of inheritance rights, execution of executive inscriptions, protests of bills, etc. The implementation of notarial acts involves the protection and protection of fundamental rights and freedoms of individuals and legal entities, prevents their violation.

Key words: notary, regulatory framework, law enforcement function of the state, regulatory framework, legislation, powers. 
Постановка проблеми та іï актуальність. Стаття 3 Конституції України проголошує людину, їі життя і здоров'я, честь і гідність, недоторканність і безпеку найвищою соціальною цінністю [1]. Україна як демократична, соціальна та правова держава бере на себе зобов'язання щодо створення належних умов життя іiі громадян через виконання відповідних функцій, реалізація яких формує комфортне середовище для розвитку суспільства загалом і людини зокрема. Одне з ключових завдань держави - це охорона прав та інтересів ії громадян, що забезпечується через реалізацію нею правоохоронної функції. Нормативного закріплення правоохоронної функції держави в національному законодавстві не існує, а іiі реалізація відбувається через діяльність органів влади, які наділені відповідними повноваженнями.

Відмітимо досить значну кількість нормативно-правових актів, особливо підзаконних, які регулюють нотаріальну діяльність в Україні, що певною мірою створює труднощі в їх застосуванні. Така ситуація викликає необхідність реформування законодавства України про нотаріат, його систематизацію, зокрема кодифікацію, що й зумовлює актуальність дослідження.

Аналіз останніх досліджень і публікацій. Дослідженню нормативно-правових засад діяльності нотаріату в Україні присвячено праці таких учених-науковців: В. Баранкова, Г. Гулєвської, М. Долинської, В. Комарова, О. Неліна, Г. Романовського, П. Фріса, Є. Фурси, С. Фурси, В. Черниша й інших. Проте досліджувана тематика залишається актуальною й до сьогодні.

Метою статті $\epsilon$ аналіз нормативно-правових засад, що визначають здійснення нотаріатом правоохоронної функції держави.

Виклад основного матеріалу. Насамперед зупинимося на аналізі національного законодавства, яке регулює питання забезпечення й охорони прав і свобод фізичних і юридичних осіб органами нотаріату. Конституція України $є$ основним законом держави, який установлює засади конституційного ладу, має найвищу юридичну силу, а прийняті в державі нормативно-правові акти повинні відповідати ії положенням. Стаття $92 \mathrm{Koн-}$ ституції України зазначає, що виключно законами України визначаються судоустрій, судочинство, статус суддів; засади судової експертизи; організація й діяльність прокуратури, нотаріату, органів досудового розслідування, органів та установ виконання покарань; порядок виконання судових рішень; засади організації й діяльності адвокатури [1]. Отже, підкреслюється особлива роль згаданих інститутів, зокрема й нотаріату, у державі та суспільстві.

Основний Закон держави проголошує Україну суверенною, незалежною, демократичною, соціальною, правовою [1]. Утілення в життя цього положення можливе лише завдяки створенню умов для дотримання та захисту особистих, політичних, економічних, соціальних, культурних, екологічних прав і свобод людини. Держава забезпечує можливість їх реалізації через надання гарантій, зокрема ст. 59 Конституції України гарантує право кожного на професійну правничу допомогу [1]. Рішення Конституційного Суду України від 16 листопада 2000 року № 13-рп/2000 містить тлумачення цієї норми. Держава в особі відповідних органів визначає певне коло суб'єктів надання правової допомоги та їхні повноваження. Серед них виділяють державні органи
України, до компетенції яких входить надання правової допомоги, - Міністерство юстиції України, Міністерство соціальної політики України, нотаріат тощо [2]. Отже, законодавство за повноваженнями нотаріату визначає його як суб'єкта надання правової допомоги, що водночас зараховує його до складників механізму держави й інститутів громадянського суспільства. У цьому випадку варто погодитися з думкою К.І. Чижмарь, що нотаріат доцільно розглядати як конституційно-правовий інститут, що являє собою сукупність правових норм, які регулюють на основі поєднання публічних і приватних інтересів суспільні відносини в сфері організації нотаріату й нотаріальної діяльності з метою захисту гарантованих Конституцією України конституційних прав і свобод людини та громадянина [3, с. 18].

Законодавство України вказує, що нотаріуси й уповноважені на здійснення нотаріальних дій особи в процесі виконання своїх повноважень вирішують лише безспірні справи, тобто безсумнівні, ураховуючи оцінку наданих документів, які не містять розбіжностей і суперечностей. Завдання нотаріусів - перевірити наявність усіх підстав для посвідчення юридичних фактів: правочинів (договорів, заповітів, довіреності, вимоги про нотаріальне посвідчення тощо), фактів, що фізична особа $є$ живою або виконавцем заповіту, перебування ії в певному місці, час пред'явлення документів, справжність підпису на документах, правильність перекладу документів з однієї мови іншою тощо. Нотаріус, згідно зі ст. 44 Закону України «Про нотаріат», зобов'язаний установити дійсні наміри кожної зі сторін до вчинення правочину, який він посвідчує, а також відсутність у сторін заперечень щодо кожної з умов правочину. Визначення дійсних намірів кожного з учасників правочину здійснюється шляхом установлення нотаріусом однакового розуміння сторонами значення, умов правочину та його правових наслідків для кожної зі сторін [4]. Порядок учинення нотаріальних дій нотаріусами України, затверджений Наказом Міністерства юстиції України від 22 лютого 2012 року № 296/5, більш детально встановлює послідовність дій для визначення обсягу цивільної дієздатності фізичної або юридичної особи, перевірки повноважень представника фізичної або юридичної особи, установлення волевиявлення та дійсних намірів особи під час учинення нотаріальних дій, витребування відомостей і документів, необхідних для вчинення нотаріальної дії тощо [5]. Результатом дотримання всіх вимог $\epsilon$ вчинення нотаріальної дії.

Відмітимо, що нотаріус під час діяльності керується законодавством України та вчиняє лише ті дії, які йому відповідають. Однією з найважливіших нотаріальних дій, що гарантує захист майнових прав громадян, $є$ посвідчення договорів відчуження нерухомого майна. Нотаріуси посвідчують правочини, нотаріальне посвідчення яких за законом $\epsilon$ обов'язковим або за бажанням сторін. Під час надання таких послуг нотаріуси або посадові особи, які вчиняють нотаріальні дії, мають упевнитися, що зміст угоди, яка ними посвідчується, відповідає нормам закону та справжнім намірам сторін. Законодавством передбачено обов'язкове посвідчення правочинів про відчуження й заставу майна (ст. 55 Закону України «Про нотаріат»), зокрема договору про виділ у натурі частки з нерухомого майна, що перебуває в спільній частковій або сіпальний сумісній власності (ст. ст. 364, 367, 370, 372 Цивільного 
кодексу України), договору купівлі-продажу земельної ділянки, єдиного майнового комплексу, житлового будинку (квартири) або іншого нерухомого майна (ст. 657 Цивільного кодексу України, ст. 128 Земельного кодексу України), договору застави нерухомого майна, космічних об'єктів, транспортних засобів, що підлягають державній реєстрації (ст. 13 Закону України «Про заставу»), іпотечного договору (ст. 18 Закон України «Про іпотеку») тощо. Водночас нотаріус має право накласти заборону на відчуження нерухомого майна (ст. 73 Закону України «Про нотаріат»). Варто відмітити, що роль нотаріусу в процесі посвідчення вказаних правочинів полягає в охороні прав та інтересів людини та громадянина шляхом надання консультацій із юридичних питань, тлумачення норм законодавства щодо суб'єктивних обставин справи чи особливостей укладання певної угоди. Позаяк особа, яка звернулася до нотаріуса, може повною мірою не усвідомлювати наслідки вчинюваних нею дій через незнання законодавства або нерозуміння окремих його положень. Така ситуація може призвести до вчинення цієї особою дій, які завдають шкоду їі інтересам, честі, гідності, діловій репутації тощо. У такий спосіб нотаріуси сприяють запобіганню порушень прав і свобод людини та громадянина й підвищенню правової культури населення.

Законодавство України наділяє нотаріусів повноваженнями щодо охорони та захисту корпоративних прав. Відповідно до ст. 153 Цивільного кодексу України, «договір про створення акціонерного товариства укладається в письмовій формі, а якщо товариство створюється фізичними особами, договір підлягає нотаріальному посвідченню» [6]. Тотожна норма міститься в ст. 9 Закону України «Про акціонерні товариства» від 17 вересня 2008 року № 514-VI [7]. За вказаним Законом, нотаріальному посвідченню підлягає підпис фізичної особи на рішенні про створення акціонерного товариства, якщо вона створює його одноосібно (ст. 10); безвідклична довіреність із корпоративних прав (ст. 26-2); довіреність на право участі та голосування на загальних зборах, видана фізичною особою (ст. 39). Стаття 17 Закону України «Про державну реєстрацію юридичних осіб, фізичних осіб-підприємців та громадських формувань» від 15 травня 2003 року № 755-IV установлює, що нотаріальному посвідченню підлягають підписи учасників товариства з обмеженою відповідальністю або товариства з додатковою відповідальністю на рішенні загальних зборів учасників товариства про визначення розміру статутного капіталу та розмірів часток учасників або про виключення учасника з товариства, на заяві про вступ до товариства, або вихід із нього, на акті приймання-передачі частки (частини частки) у статутному капіталі товариства [8]. Отже, держава наділяє нотаріуса правами, які сприяють охороні та захисту корпоративних прав, знижує ризик здійснення неправомірних дій і протиправного відчуження майна.

Важливим аспектом під час надання нотаріальних послуг $\epsilon$ те, що подані документи, які не відповідають установленим вимогам, наприклад, містять відомості, що принижують честь, гідність і ділову репутацію фізичної особи або ділову репутацію юридичної особи, мають підчистки або дописки, закреслені слова чи інші незастережні виправлення, документи, тексти яких неможливо прочитати внаслідок пошкодження, а також документи, написані олівцем, не будуть прийняті до розгляду [4]. Така позиція законодавця $\epsilon$ зрозумілою та виправданою, адже честь, гідність особи, ії ділова репутація $\epsilon$ невід'ємними особистими правами та свободами, гарантованими державою. Недоліки в змісті тексту та його оформленні можуть вводити в оману осіб, які посвідчують певний юридичний факт, спотворити волю однієї або обох сторін. Отже, у такий спосіб нотаріус здійснює охорону й захист базових прав і свобод людини та громадянина, унеможливлює їх порушення.

Національним законодавством установлена можливість відмови в учиненні нотаріальних дій особами, які їх здійснюють. Стаття 49 Закону України «Про нотаріат» визначає перелік підстав, за наявності яких нотаріус або уповноважена на здійснення нотаріальних дій особа можуть відмовити виконувати нотаріальні дії. До них зараховують учинення дії, що суперечить законодавству України, неподання відомостей (інформації) та документів, необхідних для вчинення нотаріальної дії, дія підлягає вчиненню іншим нотаріусом або посадовою особою, яка вчиняє нотаріальні дії, $\epsilon$ сумніви в тому, що фізична особа, яка звернулася за вчиненням нотаріальної дії, усвідомлює значення, зміст, правові наслідки цієї дії або діє під впливом насильства тощо [4]. Указаний у Законі перелік не $\epsilon$ вичерпним, що, у свою чергу, покладає на нотаріусів і відповідних посадових осіб обов'язок адекватного оцінювання обставин, документів, наданих особами для вчинення нотаріальних дій, з метою захисту й охорони прав і свобод людини та громадянина, недопущення укладання правочинів, які можуть шкодити їхнім інтересам. Разом із цим у законодавстві міститься застереження щодо необґрунтованої відмови нотаріусом у вчиненні нотаріальних дій, яка може бути оскарженою у визначеному законом порядку.

Наступним способом захисту й охорони майнових прав нотаріусами, відповідно до ст. 18 Цивільного кодексу України, $\epsilon$ вчинення виконавчого напису на борговому документі [6], який установлює заборгованість або передбачає повернення майна. Закон України «Про нотаріат» передбачає умови вчинення, зміст виконавчого напису, строк пред'явлення виконавчого напису до виконання, порядок стягнення за виконавчим написом [4]. Постановою Кабінету Міністрів України визначено перелік документів, за якими стягнення заборгованості провадиться в безспірному порядку на підставі виконавчих написів нотаріусів [9], що встановлює особливості стягнення заборгованості за конкретно визначеними підставами. Якщо виконавчий напис не вміщується на документі, що встановлює заборгованість, то він має бути продовжений чи викладений повністю на прикріпленому до документа спеціальному бланку нотаріального документа [5]. Учинення виконавчого напису $\epsilon$ нотаріальною дією, спрямованою на надання документу виконавчої сили. Відповідно до ст. 3 Закону України «Про виконавче провадження» від 3 червня 2016 року № 1404-VIII, виконавчі написи нотаріусів належать до тих документів, що підлягають примусовому виконанню, поряд з іншими виконавчими документами [10]. Як відзначає Н.М. Денисяк, специфіка виконавчого напису нотаріуса зумовлена його подвійною правовою природою як виду нотаріального акта й виконавчого документа [11, с. 34]. 3 одного боку, виконавчий напис нотаріусу прирівнюється до інших 
виконавчих документів, а з іншого боку, стосується лише безспірної заборгованості або іншої відповідальності боржника за умови, що з дня виникнення права вимоги минуло не більше ніж три роки, а у відносинах між підприємствами, установами й організаціями не більше ніж один рік [4]. Отже, учинення виконавчого напису нотаріусом дає змогу вирішити справу без звернення до суду, що усуває можливість виникнення спорів між сторонами. Указана нотаріальна дія передбачає позасудове розв'язання проблеми й реалізацію законних прав та інтересів фізичних і юридичних осіб, а нотаріат, маючи відповідні повноваження, здійснює роль превентивного правосуддя.

Відмітимо, що нотаріус у межах заходів щодо захисту майнових прав фізичних і юридичних осіб здійснює охорону спадкового майна. Стаття 1283 Цивільного кодексу України та гл. 6 «Вжиття заходів до охорони спадкового майна», гл. 7 «Видача свідоцтв про право на спадщину» Закону України «Про нотаріат» регулюють питання реалізації спадкового права громадянами. Так, за Цивільним кодексом України, охорона спадкового майна здійснюється в інтересах спадкоємців, відказоодержувачів і кредиторів спадкодавця з метою збереження його до прийняття спадщини спадкоємцями або набрання законної сили рішенням суду про визнання спадщини відумерлою [6]. Стаття 60 Закону України «Про нотаріат» до переліку заінтересованих осіб зараховує також державу [4]. Нотаріус здійснює заходи, спрямовані на охорону спадкового майна, у декілька етапів: прийняття заяви про вжиття заходів щодо охорони спадкового майна, здійснення підготовчих дій, необхідних для з'ясування обставин справи (витребування і тримання всіх необхідних документів, вирішення питання щодо залучення свідків, необхідності залучення експерта тощо), опис спадкового майна, охорона та зберігання спадкового майна [12]. Порядок вчинення нотаріальних дій нотаріусами України, затверджений Наказом Мін'юсту України від 22 лютого 2012 року № 296/5м, визначає послідовність дій нотаріусів з метою охорони спадкових прав [5]. При цьому важливо розуміти, що на кожному з указаних етапів нотаріус бере на себе відповідальність щодо дотримання процедур спадкування з метою охорони майнових прав громадян і запобігання їх порушенню. У такий спосіб нотаріат виконує важливе завдання - захист набуття права власності на майно у визначений законом спосіб. Необхідно підкреслити, що в демократичній, правовій, соціальній державі право приватної власності $\epsilon$ непорушним, ніхто не може безпідставно бути позбавлений свого майна. Це право вважається ключовим у комплексі всіх прав та обов'язків людини та громадянина в Україні. Гарантія його реалізації покладається на державу, а нотаріат від іiі імені $\epsilon$ виконавцем покладених на неї обов'язків.

У межах повноважень нотаріуси здійснюють заходи щодо охорони прав подружжя, малолітніх і неповнолітніх дітей та інших родичів. Стаття 60 Сімейного кодексу України встановлює, що «майно, набуте подружжям за час шлюбу, належить дружині та чоловікові на праві спільної сумісної власності незалежно від того, що один з них не мав з поважної причини (навчання, ведення домашнього господарства, догляд за дітьми, хвороба тощо) самостійного заробітку (доходу)». Стаття 65 цього Кодексу визначає, що під час укладання одним із подружжя договорів, які потребують нотаріального посвідчення й (або) державної реєстрації, а також договорів стосовно цінного майна згода другого з подружжя має бути подана письмово. Отже, нотаріус під час посвідчення договорів обов'язково перевіряє факт перебування сторін договору у шлюбі й у разі його наявності вимагає відповідні згоди (згоду) від другого з подружжя. Захист майнових прав дітей здійснюється через накладання нотаріусом заборони на відчуження нерухомого майна та через посвідчення договорів щодо відчуження нерухомого майна за визначеним законом порядком. Так, ст. 73 Закону України «Про нотаріат» указує на право нотаріуса накласти заборону на відчуження жилого будинку, квартири, іншого приміщення, на які має право власності дитина або вона проживає в ньому. Здійснення цієї нотаріальної дії можливе за зверненням органу опіку та піклування. Відповідно до п. 3 гл. 1 розділу II Порядку вчинення нотаріальних дій нотаріусами України, визначається, що в разі посвідчення договорів за участю малолітніх/неповнолітніх осіб, а також осіб, над якими встановлено опіку або піклування, нотаріус перевіряє наявність дозволу органу опіки та піклування на укладення таких правочинів. Аналогічна вимога міститься в законодавстві щодо фізичних осіб, визнаних у судовому порядку недієздатними, а відповідні нотаріальні дії вчиняються за згодою батьків (усиновлювачів) або опікунів.

Окремо варто зазначити про захист прав членів сім'ї щодо спадкування майна. Так, стаття 71 Закону України «Про нотаріат» визначає підстави видачі свідоцтва про право власності на частку в спільному майні подружжя в разі смерті одного з них: перебування в зареєстрованому в державних органах реєстрації актів цивільного стану шлюбі та набуття майна в період перебування в шлюбі на ім'я особи, котра померла [4]. Особливою категорією спадкоємців $\epsilon$ малолітні та неповнолітні особи, які в силу фізіологічного й інтелектуального розвитку не можуть повною мірою усвідомлювати наслідки вчинюваних дій і захистити свої права. У зв'язку з цим ст. 66 Закону України «Про нотаріат» установлює, що охорона їхніх спадкових прав здійснюється нотаріусами та відповідними посадовими особами із залученням органів опіки та піклування за місцем проживання спадкоємця. Отже, охороні й (або) захисту прав суб'єктів сімейних правовідносин законодавець приділив окрему увагу не лише через захист майнових прав, які виникли у зв'язку укладання шлюбу або належності до сім'ї, а й у зв'язку 3 реалізацією державою правоохоронної функції.

Відмітимо, що особливість інституту нотаріату полягає в його правовій природі, оскільки, з одного боку, нотаріат має державно-владні повноваження, а з іншого - $\epsilon$ інститутом громадянського суспільства. Проте в будь-якому разі нотаріальна діяльність має публічний характер і здійснюється в інтересах держави загалом і людини зокрема. У межах виконання своїх функцій нотаріат створює належні умови для реалізації фізичними та юридичними особами своїх прав, сприяє формуванню соціальної, правової, демократичної держави, у якій мінімізуються порушення цих прав, здійснюються заходи щодо запобігання їх порушенню.

Аналіз законодавства України свідчить про виконання нотаріатом, який $\epsilon$ складником механізму держави, важливої правоохоронної функції, у зв'язку з чим 
на нього покладаються відповідні завдання. Здійснюючи в межах своєї компетенції, якою його наділяє держава, правозастосовну та юрисдик ційну діяльність, нотаріус виконує публічні завдання й функції щодо позасудової охорони та захисту прав і законних інтересів фізичних і юридичних осіб, територіальних громад і держави, зміцнення законності й підтримки правопорядку, запобігання протиправним діям [13, с. 134].

Висновки. Розбудова незалежної, демократичної, соціальної, правової держави потребує значної уваги до належного виконання нею відповідних функцій. Важливим фактором, який визначає вектор розвитку держави й суспільства, $є$ ставлення до людини та створення належних умов для ії життя. Аналіз змісту нормативно-правових актів України доводить, що законодавець використовує людиноцентристський підхід під час вирішення тих завдань, які на нього покладаються. Вагомим аспектом такої позиції $є$ охорона прав і свобод фізичних і юридичних осіб, унеможливлення їх порушення.

У законодавстві не існує визначення правоохоронної функції, а їі здійснення відбувається через правоохоронну діяльність відповідних суб'єктів. Нотаріат входить до складу системи правоохоронних органів в Україні, на які покладається обов'язок сприяти реалізації прав і свобод фізичних і юридичних осіб у державі. Діяльність нотаріату в Україні регулюється значною кількістю різнорівневих нормативно-правових актів, що створює труднощі в їх застосуванні. Базовим для здійснення нотаріальної діяльності $€$ Закон України «Про нотаріат». Недосконалість законодавчої бази про нотаріат і необхідність уточнення окремих понять вимагає його реформування, яке має здійснюватися в напрямі систематизації.

Нотаріуси та посадові особи, які вчиняють нотаріальні дії, вирішують лише безспірні справи, ураховуючи оцінку наданих документів, які не мають містити розбіжностей і суперечностей. Перелік нотаріальних дій і процедура їх здійснення закріплена в законодавстві. Серед них варто назвати посвідчення довіреностей, договорів відчуження нерухомого майна, земельних ділянок, земельних часток (паїв), транспортних засобів, договорів найму (оренди), договорів застави, договорів іпотеки й інших договорів, заповітів, засвідчення правильності копій (фотокопій) документів, справжності підпису на документах, здійснення відкриття спадкових справ, видача свідоцтв про право на спадщину, учинення виконавчих написів, протестів векселів тощо. Здійснення нотаріальний дій передбачає охорону та захист основних прав і свобод фізичних і юридичних осіб, унеможливлює їх порушення. У такий спосіб нотаріат здійснює правоохоронну функцію, а разом із цим $\epsilon$ інструментом реалізації правоохоронної функції державою.

\section{Література}

1. Конституція України : Закон України від 28 червня 1996 року № 254к/96-BP. URL: https://zakon.rada.gov.ua/ laws/show/254\%D0\%BA/96-\%D0\%B2\%D1\%80.

2. Рішення Конституційного Суду України у справі за конституційним зверненням громадянина Солдатова Геннадія Івановича щодо офіційного тлумачення положень статті 59 Конституції України, статті 44 Кримінально-процесуального кодексу України, статей 268, 271 Кодексу України про адміністративні правопорушення (справа про право вільного вибору захисника) від 16.11.2000 № 13-рп/2000. URL: https: / / zakon.rada.gov.ua/laws/show/v013p710-00\#n54.

3. Чижмарь К.І. Теоретико-правові основи нотаріату в Україні. Навчальний. посібник / за загальною редакцією К.І. Чижмарь. Київ : Центр учбової літератури, 2016. 200 с.

4. Про нотаріат : Закон України від 2 вересня 1993 року № 3425-XII. URL: https://zakon.rada.gov.ua/laws/ show/3425-12/stru\#Stru.

5. Про затвердження Порядку вчинення нотаріальних дій нотаріусами України : Наказ Міністерства юстиції України від 22 лютого 2012 року № 296/5. URL: https://zakon. rada.gov.ua/laws/show/z0282-12.

6. Цивільний кодекс України : Закон України від 16 січня 2003 року № 435-IV. URL: https://zakon.rada.gov.ua/ laws/show/435-15.

7. Проакціонернітовариства: ЗаконУкраїнивід 17вересня 2008 року № 514-VI. URL: https://zakon.rada.gov.ua/ laws/show/514-17.

8. Про державну реєстрацію юридичних осіб, фізичних осіб-підприємців та громадських формувань : Закон України від 15 травня 2003 року № 755-IV. URL: https: //zakon.rada.gov.ua/laws/show/755-15.

9. Про затвердження переліку документів, за якими стягнення заборгованості провадиться у безспірному порядку на підставі виконавчих написів нотаріусів : Постанова Кабінету Міністрів України від 29 червня 1999 року № 1172. URL: https://zakon.rada.gov.ua/laws/ show $/ 1172-99-\%$ D0\%BF.

10. Про виконавче провадження : Закон України від 3 червня 2016 року № 1404-VIII. URL: https://zakon.rada. gov.ua/laws/show/1404-19.

11. Денисяк Н.М. Актуальні питання застосування виконавчого напису в сучасній правозастосовній практиці. Наукові записки Міжнародного гуманітарного універсиmemy. 2013. № 18. С. 32-35.

12. Методичні рекомендації щодо вчинення нотаріальних дій, пов'язаних із вжиттям заходів щодо охорони спадкового майна, видачею свідоцтв про право на спадщину та свідоцтв про право власності на частку в спільному майні подружжя, Міністерства юстиції України від 29 січня 2001 року. URL: https://zakon.rada.gov.ua/laws/show/ n0001323-09.

13. Юрченко В. Мета, завдання та функції нотаріуса в умовах реформування юстиції України. Український часопис міжнародного права. 2013. № 1. С. 131-134.

Савицька Н. А., аспірант кафедри публічного управління та адміністрування Національної академії внутрішніх справ 